\title{
Öğretmen Adaylarının Empatik Eğilimlerinin Sosyal Girişimcilik Özelliklerini Yordama Gücü ve Empatik Eğilim ile Sosyal Girişimcilik Özelliklerini Etkileyen Faktörler*
}

\section{Examining Predictive Role of Preservice Teachers'Empathic Tendency on Social Entrepreneurship Characteristics and Factors Affecting Empathic Tendencies and Social Entrepreneurship Characteristics}

\author{
Baykal BİÇER, ${ }^{a}$ Enis Harun BAŞER ${ }^{\mathrm{b} * *}$ \\ ${ }^{a}$ Doç. Dr., Kütahya Dumlupınar Üniversitesi, Eğitim Fakültesi, Türkçe ve Sosyal Bilimler Eğitimi Bölümü, Kütahya/Türkiye. \\ ORCID: 0000-0003-1494-6975

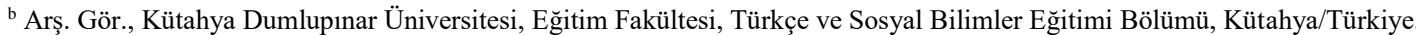 \\ ORCID: 0000-0002-9256-3454
}

\section{MAKALE BILGİSİ}

\section{Makale Geçmişi:}

Başvuru tarihi: 01 Şubat 2019

Düzeltme tarihi: 02 Nisan 2019

Kabul tarihi: 11 Nisan 2019

Anahtar Kelimeler:

Empatik Eğilim

Öğretmen Adayları

Sosyal Girişimcilik
ÖZ

$\mathrm{Bu}$ araștırma, öğretmen adaylarının sosyal girişimcilik özellikleri ile empatik eğilimleri arasındaki ilişkiyi belirlemek amacıyla ilişkisel tarama modelinde tasarlanmıştır. Araştırmanın örneklemini, Kütahya Dumlupınar Üniversitesi Eğitim Fakültesi'nde öğrenim gören 500 öğretmen adayı oluşturmaktadır. Öğretmen adaylarının 124'ü (\%24.8) kadın, 376'sı (\%75.2) erkektir. Veriler, Empatik Eğilim Ölçeği (Dökmen, 1988) ve Sosyal Girişimcilik Özellikleri Ölçeği (Konaklı ve Göğüş, 2013) kullanılarak, 2017-2018 eğitim-öğretim yılı bahar döneminde araştırmacılar tarafından toplanmıştır. Verilerin analizinde bağımsız gruplar için t-testi, tek yönlü varyans analizi ve basit doğrusal regresyon analizi kullanılmıștır. Araştırma sonucunda öğretmen adaylarının sosyal girişimcilik puanlarının yaş, bölüm ve sınıf değişkenlerinde; empatik eğilim puanlarının ise cinsiyet, yaş, bölüm, sınıf ve akademik not ortalaması değişkenlerinde anlamlı farklılık gösterdiği tespit edilmiştir. Araştırmada öğretmen adaylarının empatik eğilimlerinin sosyal girişimcilik özelliklerinin \%23’ünü yordadığı belirlenmiştir.

\section{A B S T R A C T}

This study was designed as correlational survey model to determine relationship between preservice teachers' social entrepreneurship characteristics and empathic tendencies. Sample group consists of 500 preservice teachers (124 female, 376 male)who studying at Kütahya Dumlupinar University Faculty of Education.Data were obtainedby researchers in the spring term of 2017-2018 academic year, using Empathic Tendency Scale (Dökmen, 1988) and Social Entrepreneurship Characteristics Scale (Konaklı and Göğ̈̈ş, 2013).In analysis t-test for independent groups, oneway ANOVA and simple linear regression analysis were used. As a result of study, it was determined that social entrepreneurship scores differed significantly between groups in terms of age, department and grade variables. Empathic tendency scores differed significantly between groups in terms of gender, age, department, grade, academic average variables. It was determined that preservice teachers' empathic tendencies predicted $23 \%$ of social entrepreneurship characteristics.

\section{Giriș}

Modern toplumları derinden etkileyerek küresel boyutlara ulaşan ve çeşitlilik gösteren sosyolojik sorunların artması, bilim, teknoloji ve akademi çevrelerinde bu sorunlara yönelik kalıcı, yenilikçi ve kökten çözüm arayışlarını da beraberinde getirmektedir. $\mathrm{Bu}$ arayış, sosyal problemlerin istenilen niteliklerde çözüme kavuşturulması açısından son yıllarda sosyal girişimcilik kavramını ön plana çıkarmaktadır.

*Bu çalışma, 23-25 Mart 2018 tarihleri arasında “Uluslararası Bilim ve Eğitim Kongresinde (UBEK-ICSE)” sunulan “Öğretmen Adaylarının Sosyal Girişimcilik Özellikleri ile Empatik Eğilimlerini Etkileyen Faktörler ve Aralarındaki İlişkinin İncelenmesi” adlı sözlü bildiriden geliştirilmiştir.

** Sorumlu yazar/Corresponding author

e-posta: enisharunbaser@gmail.com 
Girişimciliğin sadece ekonomiyle ilişkisine odaklanmanın dışında toplumsal sorumluluk yönünü vurgulayan sosyal girişimcilik,sosyal değer oluşturmak, sosyal değişimi gerçekleştirmek ya da toplumsal ihtiyaçları karşılamak amacıyla kaynakların yenilikçi bir șekilde kullanımını içeren bir süreç olarak ifade edilmektedir (Kickul ve Lyons, 2012). Aynı zamanda sosyal girişimcilik, toplumun giderek artan sorunlarını girişimci bakış açısıyla değerlendirerek yaratıcı çözümler üretmeyi ve sosyal alanda etki oluşturmayı hedefleyen bir kavramdır (Güler, 2008). Alanyazında farklı şekillerde tanımlanması kavramın sınırlarının net bir şekilde çizilmediğini göstermektedir. Örneğin, Aksoy (2013) kâr elde etme amacıyla birlikte sosyal sorunları işletme yöntemleriyle toplumun yararına çözmenin sosyal girişimcilik olduğunu ifade ederken, Fowler (2000) sosyal girişimciliği sürdürülebilir toplumsal faydaya yönelik yapılanma ve uygulamalar yaratmak şeklinde tanımlamaktadır. Dees (1998) ise sosyal girişimciliğin kâr amacı güden-gütmeyen veya her iki şekilde de hayata geçirilebilen sosyal fayda odaklı, yaratıcı ve sürdürülebilir sonuçlar ortaya çıkarmayı amaçladığını vurgulamıştır. Genel olarak alanyazındaki tanımlamalara bakıldığında üç farklı tema ortaya çıkmaktadır. Birincisi toplumsal değerler oluşturmak için kâr amacı gütmeyen girişimleri, ikincisi farklı sektörlerle iş birliği yaparak sosyal sorumluluk kapsamında işletmelerin yaptığı uygulamaları, üçüncüsü ise sosyal sorunları sosyal dönüşümü gerçekleştirerek çözmeyi vurgulamaktadır (Mair ve Marti, 2006).

Sosyal girişimcilik, toplumsal ihtiyaçların karşılanması ve sosyal problemlerin çözümü için kaynaklar oluşturmayı, bu kaynakları farklılık yaratan çözümler üretmek için değerlendirmeyi, sosyal etki oluşturmayı, sürdürülebilirliği, risk almayı ve inisiyatif kullanmayı içinde barındıran bir süreçtir (Besler, 2010). Bu sosyal değişim sürecinde aktif rol alan bireyler ise sosyal girişimcilerdir. Sosyal girişimci en sade ifade ile toplumsal fayda üretimini kendine amaç edinen kişidir (Aksoy, 2013). Sosyal girişimci bireyler sosyal değerler oluşturan ve bunu sürdürmeyi kendine misyon olarak benimseyen, bu misyona hizmet etmek için yeni firsatlar oluşturan ve kararlılıkla peşinde koşan yenilikçi (Dees, 1998), hassas, mücadeleci, toplumun sorunlarının bilincinde, bu sorunlara çözüm arayan bir yapıdadır (Betil, 2010).Söz konusu nitelikler incelendiğinde sosyal girişimcilerin, toplumsal sorunların çözümü için kararlılıkla uğraşan bireyler olduğu söylenebilir.

$\mathrm{Bu}$ bağlamda toplum yararına, toplum için toplumsal sorunlarla ilgilenen, bireysel enerjisini hem kendisi için hem de sosyal çevresi için kullanan bireylerin empati becerilerinin sosyal girişimci özellikleri ile ilişkili olduğu düşünülmektedir. Sosyal girişimciliğin özünde yer alan bir işi girişimci bir ruhla üstlenirken başkalarının da bu işle ilgili duygu ve düşüncelerini hesaba katma, sorunları çözerken başkalarının bakış açısıyla da bakarak en ideal çözümü arama durumlarının empatinin tanımında da vurgulandığı görülebilir. Dökmen'e (1998) göre empati bireyin kendini bir başkasının yerine koyabilmesi, onun bakışıyla dünyaya bakabilmesi, duygu ve düşüncelerini hissetmesi ve bu durumu karşısındakine iletebilmesi olarak tanımlanmaktadır. Alanyazında bu iki kavramın ilişkili olduğunu işaret eden araştırmalar mevcuttur. Mair ve Noboa (2003) sosyal girişim yaratmaya dönük davranışsal amaçların empati ve ahlaki yargı gibi tutumlardan etkilendiğini ileri sürmektedirler. Benzer şekilde sosyal girişimcilikle ilişkili bir olgu olarak görülen başkalarına yardım etme davranışıyla empati ilişkisini destekleyen çalışmalar da mevcuttur. Buna göre empati ile başkalarına yardım etme davranışı arasında pozitif yönde bir ilişki vardır (Barnett, Thompson ve Pfeifer, 1984; Goldman, Broll ve Carrill, 1983). Nitekim Zahra, Rawhouser, Bhawe, Neubaum ve Hayton'un da (2008) belirttiği üzere olumlu sosyal davranışlar empati tarafından yönlendirilir. $\mathrm{Bu}$ bilgiler sosyal girişimcilik ve empatinin birbirleriyle ilişkili kavramlar olduğunu göstermektedir.

Bireyin kişisel yeteneklerini geliştirmek, toplumun bir bütün olarak işlemesini sağlamak, sağlıklı bir toplum oluşturmak eğitim sistemlerinin temel hedefleri arasında yer almaktadır. Sosyal girişimcilik ise bu hedefe ulaşmada yardımcı olabilecek vasıtalardan biri olarak görülebilir. Öğretim programlarında doğrudan yer almasa da ulaşılması beklenen amaçlar bölümünde dolaylı olarak sosyal girişimciliğe değinen ifadeler yer almaktadır. Örneğin sosyal bilgiler dersi öğretim programının genel amaçlarında yer alan 13, 14 ve 17 numaralı maddeler sosyal girişimciliğin kapsamına girebilecek ifadelerdir. Empati ise eğitim sistemimizde öğrencilere kazandırılması beklenen temel becerilerden biridir(MEB, 2018). $\mathrm{Bu}$ becerileri yetişen nesle kazandırmak ise öğretmenlerin ve öğretmen adaylarının görevleri arasında yer almaktadır. Dolayısıyla kazandırılması beklenen bu becerilerin halihazırda ne durumda olduğunun bilinmesi olası uygulamalar için temel oluşturacaktır. $\mathrm{Bu}$ doğrultuda bu araştırmanın temel problemini;“Öğretmen adaylarının empatik eğilimleri sosyal girişimcilik özelliklerini yordamakta mıdır? Sosyal girişimcilik özellikleri ile empatik eğilimlerini etkileyen faktörler nelerdir?" soruları oluşturmaktadır. Bu bağlamda bu araştırmanın amacı öğretmen adaylarının sosyal girişimcilik özellikleri ile empatik eğilimlerini etkileyen faktörleri ve empatik eğilimin sosyal girişimciliği yordama düzeyini incelemektir. Bu kapsamda araştırmada aşağıdaki sorulara yanıt aranmıştır:

(i) Öğretmen adaylarının sosyal girişimcilik ve empatik eğilim düzeyleri ne seviyededir?

(ii) Öğretmen adaylarının sosyal girişimcilik ve empatik eğilim düzeyleri; cinsiyet, bölüm, yaş, sınıf, akademik not ortalaması, aileyle birlikte yaşanılan yer, STK üyeliği ve STK aktivitelerine katılım değişkenlerine göre gruplar arası istatistiksel olarak anlamlı bir farklılık göstermekte midir?

(iii) Öğretmen adaylarının empatik eğilimleri sosyal girişimcilik özelliklerini yordamakta mıdır?

Araştırma sorularının yanıtlanmasının, öğretmen adaylarının şu anki sosyal girişimcilik düzeylerine yönelik bir anlayışa sahip olmada ve sosyal girişimcilik düzeylerini etkileyen değişkenler hakkında bilgi edinerek sosyal girişimcilik düzeylerini geliştirmeye yönelik hazırlanacak uygulamalar için yararlanabilecek bilgiler elde etmede fayda sağlayacağı düşünülmektedir. Aynı zamanda Türkiye'de alanyazında girişimcilikle ilgili (Aydın ve Öner, 2016; Ballı ve Koca Ballı,2014; Salik ve Kaygın, 2016; Yavuz ve Yavuz, 2017), sosyal girişimcilikle ilgili (Ateș, 2018; Koçak ve Özdemir, 2015) ve empatiyle ilgili (Akbulut ve Sağlam, 2010; Alver, 1998; Çelik, 2008; Dinçyürek, 2004; Dökmen, 1987; Ekinci ve Aybek, 2010; 
Genç ve Kalafat, 2010; Koç, 2016; Pala, 2008;TutarelKışlak ve Çabukça, 2002; Ünal, 1997) çeşitli çalışmalar yer almasına rağmen empati ve sosyal girişimciliği birbiriyle ilişkilendiren bir çalışmaya rastlanmamıştır. Bu bağlamda araştırmanın alanyazına bu konuda katkı yapacağı düşünülmektedir.

\section{Yöntem}

$\mathrm{Bu}$ bölümde araştırma deseni, evren ve örneklem, kullanılan veri toplama araçları, veri toplama süreci ve verilerin analizi ile ilgili bilgiler sunulmuştur.

\subsection{Araştırma Deseni}

Araştırmada,öğretmen adaylarının sosyal girişimcilik özellikleri ile empatik eğilimlerini etkileyen faktörler ve empatik eğilimin sosyal girişimcilik özelliklerini yordama düzeyiincelenmesi amaçlandığı için ilişkisel tarama modelinin kullanılması zorunlu hale gelmiştir.Dolayısıyla araştırma, nicel araştırma yöntemlerinden ilişkisel tarama modeline uygun olarak tasarlanmıştır. Korelasyon ve karşılaştırma olmak üzere iki türü bulunan ilişkisel tarama modeli, iki ve daha çok değişken arasındaki değişimin varlığını ve/veya ilişkinin gücünü belirlemeye yarayan bir araştırma modelidir (Karasar, 1995).Bu araştırmada hem iki değişken arasındaki ilişkiye bakıldığı hem de bağımsız değişkene göre gruplar arası istatistiksel olarak anlamlı fark olup olmadığına bakıldığı için ilişkisel tarama modelinin iki türünden de yararlanılmıştır.

\subsection{Evren ve Örneklem}

Araştırmanın evrenini Kütahya Dumlupınar Üniversitesi Eğitim Fakültesi'nde 2017-2018 eğitim-öğretim y1lında öğrenim gören öğretmen adayları oluşturmaktadır. Örneklem ise, uygun örnekleme yöntemine uygun bir biçimde evrenden ulaşılabilen öğretmen adaylarından oluşmaktadır. $\mathrm{Bu}$ doğrultuda yapılan çalışmalar sonucu gönüllülük ilkesi gözetilerek 514 öğretmen adayına ulaşılabilmiştir. Eksik, hatalı, uç değer niteliği taşıyan veya geçersiz doldurulan 14 adet form analizden çıkarılmış, araştırma 500 adet form üzerinden devam ettirilmiştir.

Tablo 1.Demografik Bilgiler

\begin{tabular}{|c|c|c|c|}
\hline \multicolumn{2}{|c|}{ Özellikler } & $\mathrm{f}$ & $\%$ \\
\hline \multirow{2}{*}{ Cinsiyet } & Erkek & 376 & 75,2 \\
\hline & Kadın & 124 & 24,8 \\
\hline \multirow{3}{*}{ Yaş } & $18-20$ & 203 & 40,6 \\
\hline & $21-22$ & 200 & 40 \\
\hline & 23 ve üzeri & 97 & 19,4 \\
\hline \multirow{4}{*}{ Bölüm } & Sınıf Öğretmenliği & 190 & 38,0 \\
\hline & Okul Öncesi & 142 & 28.4 \\
\hline & Öğretmenliği & 142 & 28,4 \\
\hline & $\begin{array}{l}\text { Sosyal Bilgiler } \\
\text { Öğretmenliğgi }\end{array}$ & 168 & 33,6 \\
\hline \multirow{4}{*}{ Sinif } & 1. Sinif & 112 & 22,4 \\
\hline & 2. Sinif & 124 & 24,8 \\
\hline & 3. Sinif & 163 & 32,6 \\
\hline & 4. Sinif & 101 & 20,2 \\
\hline \multirow{4}{*}{$\begin{array}{l}\text { Aileyle Birlikte Yaşanılan Yerin } \\
\text { Niteliği }\end{array}$} & Köy & 84 & 16,8 \\
\hline & Kasaba & 51 & 10,2 \\
\hline & Şehir & 191 & 38,2 \\
\hline & Büyükşehir & 174 & 34,8 \\
\hline \multirow{3}{*}{$\begin{array}{l}\text { Herhangi Bir Sivil Toplum } \\
\text { Kuruluşuna Üye Olanlar }\end{array}$} & Evet & 128 & 25,6 \\
\hline & Hayır & 372 & 74,4 \\
\hline & Toplam & 500 & 100 \\
\hline \multirow{2}{*}{ Akademik Not Ortalaması } & $0-2,49$ & 50 & 11,2 \\
\hline & $2,50-2,99$ & 162 & 36,2 \\
\hline
\end{tabular}

\begin{tabular}{llll} 
& $3,00-3,49$ & 199 & 44,4 \\
& $3,50-4,00$ & 37 & 8,3 \\
& Toplam & 448 & 100 \\
\hline Sivil Toplum Kuruluşlarında En & Evet & 105 & 31,9 \\
Az Bir Aktiviteye Katılanlar & Haylr & 224 & 68,1 \\
& Toplam & 329 & 100 \\
\hline
\end{tabular}

Veri toplama araçları tam doldurulmuş ancak demografik bilgileri eksik girilmiş formlar, ilgili değişkenlere göre yapılacak analizlerde analiz kapsamı dışında bırakılmıştır. Araştırmaya katılan öğretmen adaylarının demografik değişkenlerle ilgili bilgileri Tablo 1'de yer almaktadır.

\subsection{Veri Toplama Araçları}

Araştırma verileri iki bölümden oluşan, üç veri toplama aracı ile toplanmıştır. Birinci bölümde katılımcıların kişisel bilgileri kısmında; cinsiyet, yaş, bölüm, sınıf, akademik not ortalaması, aile ile birlikte yaşanılan yerin niteliği, STK üyeliği ve STK kapsamında herhangi bir aktiviteye katılıp katılmama değişkenleri yer almıştır. İkinci bölümünde ise asıl veri toplama aracı olan Konaklı ve Göğüş (2013) tarafindan geliştirilen Sosyal Girişimcilik Özellikleri Ölçeği ve Dökmen (1988) tarafından geliştirilen Empatik Eğilim Ölçeği kullanılmıştır. Sosyal Girişimcilik Özellikleri Ölçeği 21 maddeden, Empatik Eğilim Ölçeği ise 20 maddeden oluşmaktadır. Sosyal Girişimcilik Özellikleri Ölçeğinden alınabilecek en yüksek puan 105, en düşük puan ise 25 'tir. Empatik Eğilim Ölçeğinden alınabilecek en yüksek puan 100 , en düşük puan ise 20 'dir.

Örneklem grubunda güvenilir verilerin toplanıp toplanmadığının belirlenmesi için iç tutarlık katsayısı (Cronbach's Alpha) hesaplanmıştır. Bu araştırmada elde edilen verilerin iç güvenirlik katsayısı Sosyal Girişimcilik Özellikleri Ölçeği için .83, Empatik Eğilim Ölçeği için .74 olarak belirlenmiştir. Güvenirlik katsayısının .70 ve daha yüksek olması test puanlarının güvenilirliği için genel olarak yeterli görülmektedir (Büyüköztürk, 2016).Elde edilen verilerin geçerliği ve güvenirliğini sağlamak adına iç güvenirlik katsayısına ek olarak birtakım hususlara da dikkat edilmiştir. Ölçeklerin ayırt edicilik gücünü belirlemeye yönelik her bir ölçek için üst grup ve alt grup Empatik eğilim ve sosyal girişimcilik puanları, ortalamaları arasındaki farkın $\mathrm{t}$ değeri hesaplanmıştır. Öncelikle ilgili puanlar yüksekten düşüğe doğru sıralanmış; alt ve üst gruplar tüm anketlerin \%27'sini oluşturan 135'er kişiden oluşturulmuştur. Ölçeklerde \%27'lik alt grup ve üst grupları arasında anlamlı bir fark olduğu görülmüştür. $\mathrm{Bu}$ fark ölçeklerin alt ve üst grupları ayırt edebildiğini göstermektedir. Ayrıca araştırmada kullanılan ölçeklerin, benzer örneklemin(öğretmen adaylarının) katılımıyla geliştirilmiş olmasına dikkat edilmiştir. Katılımcıların gönüllü olma durumları da geçerlik ve güvenirliği etkilediği için(Yıldırım ve Şimşek, 2008)yalnızca gönüllü katılımcılardan veri toplanmıştır. Sonuçları etkileyecek bir diğer durum da uç değerlerdir.Bu nedenle uç değer niteliği taşıyan formlar analiz dışı bırakılmıştır.

\subsection{Verilerin Toplanmas1}

Araştırma verileri, 2017-2018 eğitim-öğretim yılı bahar döneminde araştırmaya gönüllü olarak katılan öğretmen adaylarından elde edilmiştir. Uygulama öncesi katılımcılara araştırmanın amacı ile ilgili açıklamalar yapılmış ve 
gönüllü olan öğretmen adaylarının uygulamaya katılmaları istenmiştir. Katılımcılara, araştırmada gizliliğin esas alındığ 1 , formlara isim yazılmaması gerektiği vurgulanmış ve elde edilen verilerin herhangi bir kişi veya kurumla paylașılmayacağına dair güvence verilmiştir.Ölçek formları bizzat araştırmacılar tarafından öğretim üyelerinin izni alınarak lisans derslerinden yaklaşık 10-15 dakika önce gönüllü katılımcılara elden dağıtılmış ve tamamlandıktan sonra yine araştırmacılar tarafından toplanmıştır.Formların doldurulması yaklaşık 15 dakika sürmüştür.

\subsection{Verilerin Analizi}

Hangi istatiksel analiz tekniğinin kullanılacağını belirlemek için toplanan verilerin parametrik istatiksel tekniklere ilişkin varsayımları karşılama durumu incelenmiştir. Bu kapsamda öğretmen adaylarının sosyal girişimcilik ve empatik eğilim puanlarının normal dağılım özelliği gösterip göstermediğine bakılmıştır. Öğretmen adaylarının ölçeklerden aldıkları puanlara ilişkin; çarpıklık ve basıklık katsayıları, normal dağılım eğrisinin çizdirildiği histogram, Q-Q Plot grafiği, kutu-çizgi grafiği incelenmiştir. Çarpıklık ve basıklık değerlerinin -1 ile +1 arasında olduğu görülmüş; buna bağlı olarak da incelenen grafiklerin normal dağılıma yakın olduğu tespit edilmiştir.

Yapılan incelemeler verilerin her iki ölçek için de normal dağılım özelliği göstermesi ve diğer varsayımları karşılaması gerekçesiyle parametrik tekniklerin kullanılabileceğini göstermiştir. Öğretmen adaylarının sosyal girișimcilik ve empatik eğilim düzeylerini incelemek için betimsel analiz, her bir ölçek için değişkenlere göre gruplar arasında anlamlı bir farklılık olup olmadığını incelemek için ilişkisiz (bağımsız) gruplar için t-testi ve tek yönlü varyans (ANOVA) analizi, sosyal girişimcilik ve empatik eğilimleri arasında ilişkiyi incelemek içinse basit doğrusal regresyon analizi kullanılmıştır. Verilerin çözümlenmesinde anlamlılık düzeyi .05 olarak kabul edilmiştir.

\section{Bulgular ve Yorumlar}

$\mathrm{Bu}$ bölümde ilk olarak öğretmen adaylarının sosyal girişimcilik ve empatik eğilim düzeylerine ilişkin elde edilen bulgulara yer verilmiş, ardından ölçek puanlarının ilgili değişkenlere göre gruplar arası anlamlı farklılık gösterip göstermediğine dair ulaşılan bulgular aktarılmıştır. Son olarak, empatik eğilim ve sosyal girişimcilik ilişkisine dair elde edilen veriler sunulmuştur.

Öğretmen adaylarının sosyal girişimcilik ve empatik eğilim ölçeklerinden elde ettikleri puanların genel dağılımı Tablo 2'de sunulmuştur.

Tablo 2. Öğretmen Adaylarının Sosyal Girişimcilik (S.G.) ve Empatik Eğilim (E.E.) Ölçeklerinden Elde Ettikleri Puanların Genel Dağıllımı

\begin{tabular}{cccccc}
\hline Ölçek & $\begin{array}{c}\text { Kat1lımc1 } \\
\text { Sayıs1 }\end{array}$ & $\begin{array}{c}\text { En Düşük } \\
\text { Değer }\end{array}$ & $\begin{array}{c}\text { En Yüksek } \\
\text { Değer }\end{array}$ & $\bar{X}$ & SS \\
\hline SG & 500 & 54 & 103 & 81 & 8.57 \\
EE & 500 & 42 & 94 & 68 & 8.98 \\
\hline
\end{tabular}

Tablo 2'de görüldüğü gibi her iki ölçekten alınan puanlar incelendiğinde, sosyal girişimcilik (SG) ve empatik eğilim (EE) ölçeklerinden elde edilen puanların aritmetik ortalamalarının sırasıyla 81 ve 68 olduğu görülmektedir.
Öğretmen adaylarının sosyal girișimcilik özellikleri ve empatik eğilimleri puan ortalamalarının cinsiyete göre anlamlı düzeyde bir farklılaşma gösterip göstermediğini belirlemek için uygulanan bağımsız örneklemler için t- testi sonuçları Tablo 3 'te sunulmuştur.

Tablo 3.Sosyal Girişimcilik ve Empatik Eğilim Ölçeği Puanlarının Cinsiyet Değişkenine Göre Farklılaşıp Farklılaşmadığını Belirlemek Üzere Yapılan Bağımsız Grup t Testi Sonuçları

\begin{tabular}{cccccccccc}
\hline \multirow{2}{*}{ Olç̧ek } & \multirow{2}{*}{ Gruplar } & \multirow{2}{*}{$\mathrm{N}$} & $\bar{X}$ & $\mathrm{SS}$ & $\mathrm{Sh}_{X}$ & \multicolumn{3}{c}{$\mathrm{t}-$ Testi } & \\
\hline \multirow{2}{*}{$\mathrm{SG}$} & Erkek & 376 & 80.85 & 8.30 & .43 & \multirow{2}{*}{1.922} & \multirow{2}{*}{498} & \multirow{2}{*}{.055} & - \\
& Kadın & 124 & 82.55 & 9.29 & .83 & & & & \\
\hline \multirow{2}{*}{$\mathrm{EE}$} & Erkek & 376 & 69.78 & 8.58 & .44 & \multirow{2}{*}{3.947} & \multirow{2}{*}{498} & \multirow{2}{*}{.000} & .42 \\
& Kadın & 124 & 65.96 & 9.59 & .86 & & & & \\
\hline
\end{tabular}

Analiz sonuçlarına göre, cinsiyet değişkeni açısından sosyal girişimciliğe $\quad\left(\mathrm{t}_{(498)}=1.922, \quad \mathrm{p}>.05\right) \quad$ ilişkin öğretmen adaylarının puanları arasında anlamlı bir fark bulunamamıştır. Empatik eğilim ölçeğinde ise, erkeklerin puan ortalaması ile $(\bar{X}=69.78)$ kadınların puan ortalaması $(\bar{X}=65.96)$ arasında erkekler lehinde anlamlı düzeyde bir fark belirlenmiştir $\left(\mathrm{t}_{(498)}=3.947, \mathrm{p}<.05\right)$. Etki büyüklüğünü tespit etmek için hesaplanan Cohen's d değeri .42 olarak belirlenmiştir. $\mathrm{Bu}$ bağlamda bu değer orta etki büyüklüğü olarak yorumlanmaktadır (Cohen, 1988).

Öğretmen adaylarının sosyal girişimcilik özellikleri ve empatik eğilimlerine ait puan ortalamalarının yaş değişkenine göre anlamlı düzeyde bir farklılaşma gösterip göstermediğini belirlemek için uygulanan tek yönlü varyans analizi sonuçları Tablo 4'te sunulmuştur.

Tablo 4.Sosyal Girișimcilik ve Empatik Eğilim Ölçeği Puanlarının Yaş Değişkenine Göre Farklılaşıp Farklılaşmadığını Belirlemek Üzere Yapılan ANOVA Sonuçları

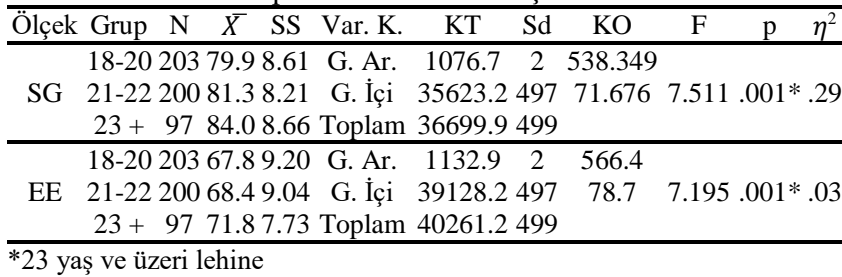

Tek yönlü varyans analizi sonuçları incelendiğinde, öğretmen adaylarının sosyal girişimcilik $\left(\mathrm{F}_{(2-497)}=.7 .511\right.$, $\mathrm{p}<.05)$ ve empatik eğilim $\left(\mathrm{F}_{(2-497)}=7.195, \mathrm{p}<.05\right)$ ölçekleri ile ilgili puanlarına ilişkin gruplar arası anlamlı bir fark olduğu görülmektedir. Bu değişimin hangi gruplar arasında olduğunu belirlemek için Scheffe çoklu karşılaştırma testi uygulanmıştır. Buna göre, her iki ölçek puanları için de 23 ve üzeri yaş grubu ile 18-20 ve 21-22 yaş grupları arasında, 23 yaş ve üzeri lehine anlamlı fark olduğu görülmüştür. Ayrıca yapılan işlemler sonucu, sosyal girişimcilik puanlarının geniş $\left(\eta^{2}=.29\right)$, empatik eğilim puanlarının iseküçük $\left(\eta^{2}=.03\right)$ etki büyüklüğüne sahip olduğu bulunmuştur.

Bölüm değişkenine göre sosyal girişimcilik özellikleri ve empatik eğilim ölçeklerinden elde edilen toplam puanlara ilişkin tek yönlü varyans analizi sonuçları Tablo 5'te sunulmuştur. 
Tablo 5. Sosyal Girişimcilik ve Empatik Eğilim Ölçeği Puanlarının Bölüm Değişkenine Göre Farklılaşıp Farklılaşmadığını Belirlemek Üzere Yapılan ANOVA Sonuçları

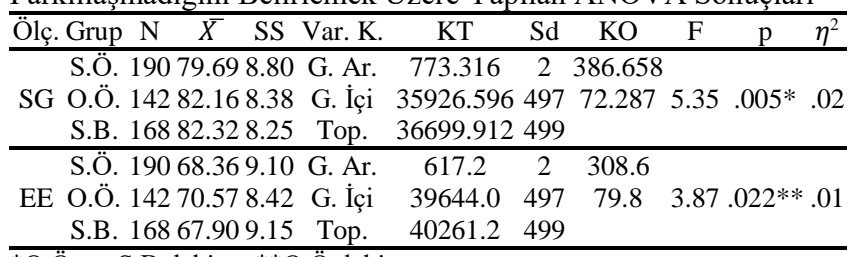
*O.Ö. ve S.B. lehine, ${ }^{* *}$ O.Ö. lehine

Tek yönlü varyans analizi sonuçları incelendiğinde, öğretmen adaylarının sosyal girişimcilik $\left(\mathrm{F}_{(2-497)}=5.349\right.$, $\mathrm{p}<.05)$ ve empatik eğilim $\left(\mathrm{F}_{(2-497)}=3.869, \mathrm{p}<.05\right)$ ölçekleri ile ilgili puanlarına ilişkin gruplar arası anlamlı bir fark olduğu görülmektedir. Scheffe çoklu karşılaştırma testi sonucuna göre sosyal girişimcilik puanlarında okul öncesi ve sosyal bilgiler öğretmenliği ile sınıf öğretmenliği bölümleri arasında okul öncesi ve sosyal bilgiler öğretmenliği lehine anlamlı fark olduğu görülmektedir. Empatik eğilim puanlarında ise, okul öncesi ve sosyal bilgiler öğretmenliği arasında okul öncesi öğretmenliği lehine anlamlı bir fark bulunmuştur. Sosyal girişimcilik $\left(\eta^{2}=.02\right)$ ve empatik eğilim puanları için küçük $\left(\eta^{2}=.01\right)$ etki büyüklüğüne sahip olduğu görülmüştür.

Sınıf değişkeni açısından sosyal girişimcilik özellikleri ve empatik eğilim ölçeklerinden elde edilen toplam puanlarına ilişkin tek yönlü varyans analizi sonuçları Tablo 6'da sunulmuştur.

Tablo 6. Sosyal Girişimcilik ve Empatik Eğilim Ölçeği Puanlarının Sınıf Değişkenine Göre Farklılaşıp Farklılaşmadığını Belirlemek Üzere Yapılan ANOVA Sonuçları

\begin{tabular}{|c|c|c|c|c|c|c|c|}
\hline Gr. N & $\bar{X}$ & SS & Var. K. & KT & $\mathrm{Sd}$ & $\mathrm{KO}$ & $\overline{\eta^{2}}$ \\
\hline 1.112 & 79.13 & 8.10 & G. Ar. & 778.7 & 3 & 259.58 & \multirow{4}{*}{$3.584 .014 * .02$} \\
\hline $\mathrm{CG}^{2 .} 124$ & 82.05 & 8.17 & G. İçi & 35921.2 & 496 & \multirow{3}{*}{72.42} & \\
\hline $\mathrm{SG}_{3.163}$ & 81.33 & 8.92 & \multirow[t]{2}{*}{ Toplam } & 36699.9 & \multirow[t]{2}{*}{499} & & \\
\hline 4. 101 & 82.63 & 8.68 & & & & & \\
\hline 1. 112 & 66.89 & 9.89 & G. Ar. & 736.493 & 3 & 245.498 & \multirow{4}{*}{$3.081 .027 * .01$} \\
\hline \multirow{3}{*}{$\begin{array}{r}\text { 2. } 124 \\
3.163 \\
4.101\end{array}$} & 68.87 & 8.53 & G. İçi & 39524.729 & 496 & 79.687 & \\
\hline & 69.06 & 9.07 & Toplam & 40261.222 & 2499 & & \\
\hline & 70.574 & .9954 & & & & & \\
\hline
\end{tabular}

*4. S. lehine

Tek yönlü varyans analizi sonuçları incelendiğinde, öğretmen adaylarının sosyal girişimcilik özellikleri $\left(\mathrm{F}_{(3-}\right.$ $\left.{ }_{496)}=3.584, \mathrm{p}<.05\right)$ ve empatik eğilim $\left(\mathrm{F}_{(3-496)}=3.081, \mathrm{p}<.05\right)$ ölçek puanlarına ilişkin gruplar arası anlamlı bir fark olduğu görülmektedir. Scheffe çoklu karşılaştırma testi sonucuna göre her iki ölçek puanları için de 1 . sınıf ve 4 . sınıf arasında 4. sinıf lehine anlamlı fark olduğu görülmüştür. Sosyal girişimcilik $\left(\eta^{2}=.02\right)$ ve empatik eğilim puanları $\left(\eta^{2}=.01\right)$ için küçük etki büyüklüğüne sahip olduğu görülmüştür.

Aile ile birlikte yaşanılan yerin niteliği değişkeni açısından sosyal girişimcilik özellikleri ve empatik eğilim ölçeklerinden elde edilen toplam puanlarına ilişkin tek yönlü varyans analizi sonuçları Tablo 7'de sunulmuştur.
Tablo 7.Sosyal Girișimcilik ve Empatik Eğilim Ölçeği Puanlarının Aile İle Birlikte Yaşanılan Yerin Niteliği Değişkenine Göre Farklılaşıp Farklılaşmadığını Belirlemek Ǘzere Yapılan ANOVA Sonuçları

\begin{tabular}{|c|c|c|c|c|c|c|c|c|c|}
\hline Ölçek & Grup & $\mathrm{N}$ & $\bar{X}$ & SS & Var. K. & KT & $\mathrm{Sd} \quad \mathrm{KO}$ & $\mathrm{F}$ & $\mathrm{p}$ \\
\hline \multirow{4}{*}{ SG } & Köy & 84 & 82.17 & 8.96 & G. Aras1 & 404.33 & $\begin{array}{ll}3 & 134.78\end{array}$ & \multirow{4}{*}{\multicolumn{2}{|c|}{1.842 .139}} \\
\hline & Kasaba & 51 & 79.96 & 6.84 & G. İçi & 36295.58 & 49673.18 & & \\
\hline & Şehir & 191 & 80.47 & 8.44 & Toplam & 36699.91 & 499 & & \\
\hline & B.Şehi & 174 & 82.12 & 8.91 & & & & & \\
\hline \multirow{4}{*}{ EE } & Köy & 84 & 68.50 & 9.48 & G. Aras1 & 91.551 & 330.517 & \multirow{4}{*}{.377} & \multirow{4}{*}{.770} \\
\hline & Kasaba & 51 & 68.53 & 9.62 & G. İçi & 40169.67 & 49680.987 & & \\
\hline & Şehir & 191 & 68.53 & 9.11 & Toplam & 40261.22 & 499 & & \\
\hline & B.Sehi & 174 & 69.42 & 8.44 & & & & & \\
\hline
\end{tabular}

Araştırmaya katılanların aile ile birlikte yaşanılan yerin niteliği değişkenine göre sosyal girişimcilik özellikleri ve empatik eğilim ölçeklerinden elde edilen toplam puanlarına ilişkin tek yönlü varyans analizi sonuçları incelendiğinde, öğretmen adaylarının sosyal girişimcilik $\left(\mathrm{F}_{(3-496)}=1.842\right.$, $\mathrm{p}>.05)$ ve empatik eğilim $\left(\mathrm{F}_{(3-496)}=.377, \mathrm{p}>.05\right)$ puanlarına ilişkin gruplar arası anlamlı bir fark olmadığı görülmektedir.

Öğretmen adaylarının sosyal girişimcilik özellikleri ve empatik eğilimleri puan ortalamalarının akademik not ortalaması değişkenine göre anlamlı düzeyde bir farklılaşma gösterip göstermediğini belirlemek için uygulanan tek yönlü varyans analizi sonuçları Tablo 8'de sunulmuştur.

Tablo 8. Sosyal Girişimcilik ve Empatik Eğilim Ölçeği Puanlarının Akademik Not Ortalaması Değişkenine Göre Farklılaşıp Farklılaşmadığını Belirlemek Üzere Yapılan ANOVA Sonuçları

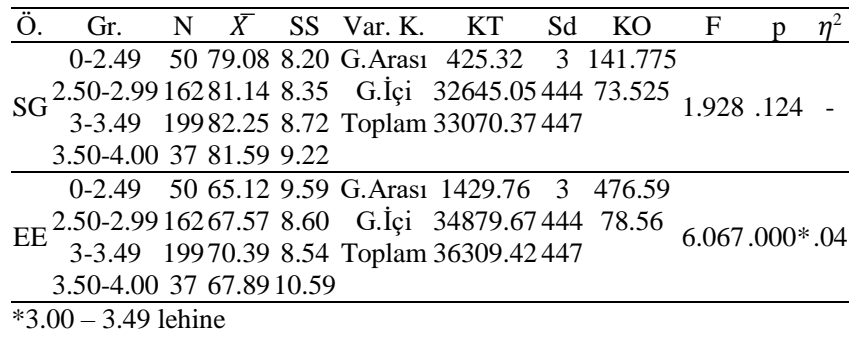

Akademik not ortalaması değişkenine göre öğretmen adaylarının sosyal girişimcilik $\left(\mathrm{F}_{(3-444)}=1.928, \quad \mathrm{p}>.05\right)$ puanlarına ilişkin gruplar arası anlamlı bir fark olmadığ görülmektedir. Ancak empatik eğilim $\left(\mathrm{F}_{(3-444)}=6.067\right.$, $\mathrm{p}<.05)$ puanlarına ilişkin gruplar arası anlamlı bir fark olduğu görülmektedir. Scheffe çoklu karşılaştırma testi sonucuna göre empatik eğilim puanlarında $0-2.49$ ve 2.50 - 2.99 ile 3.00 - 3.49 grupları arasinda 3.00 - 3.49 grubunun lehine anlamlı fark olduğu ortaya çıkmıştır. Empatik eğilim puanları $\left(\eta^{2}=.04\right)$ için küçük etki büyüklüğüne sahip olduğu görülmüştür.

Öğretmen adaylarının sosyal girişimcilik özellikleri ve empatik eğilimleri puan ortalamalarının STK üyeliği değişkenine göre anlamlı düzeyde bir farklılaşma gösterip göstermediğini belirlemek için uygulanan bağımsız örneklemler için t- testi sonuçları Tablo 9'da sunulmuştur. 
Tablo 9. Sosyal Girişimcilik ve Empatik Eğilim Ölçeği Puanlarının STK Üyelik Değişkenine Göre Farklılaşıp Farklılaşmadığını Belirlemek Üzere Yapılan Bağımsız Grup t Testi Sonuçları

\begin{tabular}{|c|c|c|c|c|c|c|c|c|}
\hline \multirow{2}{*}{ Ölçek } & \multirow{2}{*}{ Gruplar } & \multirow{2}{*}{$\mathrm{N}$} & \multirow{2}{*}{$\bar{X}$} & \multirow{2}{*}{ SS } & \multirow{2}{*}{$\mathrm{Sh}_{X}$} & \multicolumn{3}{|c|}{ t-Testi } \\
\hline & & & & & & $\mathrm{t}$ & $\mathrm{Sd}$ & $p$ \\
\hline \multirow[b]{2}{*}{ SG } & Evet & 105 & 81.8286 & 8.01256 & .78195 & \multirow[b]{2}{*}{.788} & \multirow[b]{2}{*}{327} & \multirow{2}{*}{.431} \\
\hline & Hayır & 224 & 81.0313 & 8.79329 & .58753 & & & \\
\hline \multirow[b]{2}{*}{ EE } & Evet & 105 & 69.3238 & 8.97271 & .87565 & \multirow{2}{*}{.655} & \multirow{2}{*}{327} & \multirow{2}{*}{.513} \\
\hline & Hayır & 224 & 68.5938 & 9.62527 & .64312 & & & \\
\hline
\end{tabular}

Bağımsız örneklemler için $\mathrm{t}$ - testi sonuçlarına göre STK üyeliği değiş̧keni açısından sosyal girişimciliğe $\left(\mathrm{t}_{(327)}=.788\right.$, $\mathrm{p}>.05)$ ve empatik eğilime $\left(\mathrm{t}_{(327)}=.655, \mathrm{p}>.05\right)$ ilişkin öğretmen adaylarının puanları arasında anlamlı bir fark bulunamamıştır.

Öğretmen adaylarının sosyal girişimcilik özellikleri ve empatik eğilimleri puan ortalamalarının STK aktivitelerine katılım değişkenine göre anlamlı düzeyde bir farklılaşma gösterip göstermediğini belirlemek için uygulanan bağımsız örneklemler için t- testi sonuçları Tablo 10'da verilmiştir.

Tablo 10. Sosyal Girişimcilik ve Empatik Eğilim Ölçeği Puanlarının STK Aktivitelerine Katılım Değişkenine Göre Farklılaşıp Farklılaşmadığını Belirlemek Üzere Yapılan Bağımsız Grup t Testi Sonuçları

\begin{tabular}{|c|c|c|c|c|c|c|c|c|}
\hline \multirow{2}{*}{ Ölçek } & \multirow{2}{*}{ Gruplar } & \multirow{2}{*}{$\mathrm{N}$} & \multirow{2}{*}{$\bar{X}$} & \multirow{2}{*}{ SS } & \multirow{2}{*}{$\mathrm{Sh}_{x}$} & \multicolumn{3}{|c|}{ t-Testi } \\
\hline & & & & & & $\mathrm{t}$ & $\mathrm{Sd}$ & p \\
\hline \multirow[b]{2}{*}{ SG } & Evet & 105 & 81.8286 & 8.01256 & .78195 & \multirow[b]{2}{*}{.788} & \multirow{2}{*}{327} & \multirow{2}{*}{.431} \\
\hline & Hayır & 224 & 81.0313 & 8.79329 & .58753 & & & \\
\hline \multirow[b]{2}{*}{ EE } & Evet & 105 & 69.3238 & 8.97271 & .87565 & \multirow[b]{2}{*}{.655} & \multirow[b]{2}{*}{327} & \multirow[b]{2}{*}{.513} \\
\hline & Hayır & 224 & 68.5938 & 9.62527 & .64312 & & & \\
\hline
\end{tabular}

Analiz sonuçlarına göre STK aktivitelerine katılım değişkeni açısından sosyal girişimciliğe $\left(\mathrm{t}_{(327)}=.788, \mathrm{p}>.05\right)$ ve empatik eğilime $\left(\mathrm{t}_{(327)}=.655, \mathrm{p}>.05\right)$ ilişkin öğretmen adaylarının puanları arasında anlamlı bir fark bulunamamıştır.

Empatik eğilim değişkenine göre sosyal girişimciliğin yordanmasına ilişkin basit doğrusal regresyon analizi sonuçları Tablo 11'de verilmiştir.

Tablo 11. Sosyal Girişimciliğin Yordanmasına İlişkin Basit Doğrusal Regresyon Analizi Sonuçları

\begin{tabular}{|c|c|c|c|c|c|c|c|c|c|c|}
\hline B & Sh. & $\beta$ & $\mathrm{R}$ & $\mathrm{R}^{2}$ & Adj. $\mathrm{R}^{2}$ & $\mathrm{t}$ & $\mathrm{p}$ & $\mathrm{F}$ & & EE \\
\hline$\overline{\text { Sabit } 49.64 \mathrm{C}}$ & 2.603 & & & & & 19.071 & .000 & & SG. & $.481 *$ \\
\hline EE .459 & .038 & 481 & .48 & & .230 & 12.252 & .000 & & $\mathrm{~N}$ & 500 \\
\hline
\end{tabular}

Tablo 11'de de görüldüğü gibi empatik eğilim değişkeninin sosyal girişimcilik özelliklerini istatistiksel olarak anlamlı yordadığ 1 belirlenmiştir $\left(\mathrm{R}=.48, \mathrm{R}^{2}=0,23 ; \mathrm{p}<.05\right)$. Empatik eğilim değişkeni sosyal girişimcilik özelliklerinin toplam varyansının yaklaşık olarak \%23'ünü açıklamaktadır.

\section{Tartışma, Sonuç ve Öneriler}

Araştırma sonucuna göre öğretmen adaylarının sosyal girişimcilik ve empatik eğilim düzeylerinin yüksek seviyede olduğu söylenebilir. Koçak ve Özdemir'in (2015) yapmış olduğu araştırmada da öğretmen adaylarının sosyal girişimcilik düzeyleri yüksek seviyede çıkmıştır. Benzer şekilde Aydın ve Öner'in (2016) çalışmasında da öğretmen adaylarının girişimcilik düzeyleri yüksek çıkmıştır. Empati ile ilgili araştırmalara bakıldığında ise yine araştırma sonuçlarını destekleyen çalışmalara ulaşmak mümkündür. Örneğin, Pala'nın (2008) araştırmasında öğretmen adaylarının empati seviyeleri ortanın biraz üzerinde çıkmıştır. Akbulut ve Sağlam da (2010) sınıf öğretmenlerinin empatik eğilim düzeylerinin oldukça uygun olduğu sonucuna ulaşmışlardır. Ancak Dökmen'in (1987) eğitim fakültesinde gerçekleştirdiği araştırmasında ise öğrencilerin empati seviyesi düşük bulunmuştur. Araştırmalarda sosyal girişimciliğin ve empatik eğilimin genel olarak ortalamanın üzerinde çıkmasında, öğretmenlik mesleğine yönelik verilen eğitimlerin, öğretmen yeterlikleri ve nitelikleri gibi değişkenlerin rol oynadığ düşünülebilir. Nihayetinde öğretmenlik mesleği doğası gereği, içerisinde hem empatiyi hem de sosyal girişimciliği barındırmaktadır.

Öğretmen adaylarının, cinsiyet değişkenine göre sosyal girişimcilik puanlarında gruplar arası anlamlı bir fark bulunmazken empatik eğilimleri arasında erkekler lehine anlamlı fark olduğu tespit edilmiştir. Yavuz ve Yavuz'un (2017) araştırmasında da girişimcilik eğilimi ölçeği puanlarının cinsiyet değişkeni açısından anlamlı bir farklılık göstermediği sonucuna varılmıştır. Benzer bir sonuç Neqabi ve Bahadori'nin (2012) araştırmasında da tespit edilmiştir. Ancak Ateş'in (2018) sosyal girişimcilik ile ilgili araştırmasında kadınların lehine anlamlı bir fark bulunmuştur. Empati üzerine yapılan çalışmalara bakıldığında ise,bu araştırmada elde edilen sonucun aksine kadınların lehine anlamlı farklılık tespit edilen (Akbulut ve Sağlam, 2010;Allemand,Steiger ve Fend, 2015; Ekinci ve Aybek, 2010;Hanson ve Mullis, 1985; Koç, 2016;Myyry ve Helkama, 2001; Ünal, 1997) veya gruplar arası anlamlı fark bulunmayan araştırmalara rastlamak mümkündür (Alver, 1998; Dinçyürek, 2004; Genç ve Kalafat, 2010; TutarelKışlak ve Çabukça, 2002). Araştırma sonuçlarındaki bu farklılıklar, araştırmaların gerçekleştirildiği bölgelerin sosyo-kültürel farklılıklarından kaynaklanabilir.Örneğin, öğrencilerin geldiği bölgelerin veya araştırmanın gerçekleştiği bölgenin toplumsal cinsiyet algısı erkekleri daha ön plana çıkarıyor olabilir.

Yaş değişkeni açısından incelendiğinde sosyal girişimcilik ve empatik eğilim puanlarının 23 yaş ve üzerinde olan grubun lehine anlamlı farkl1lık gösterdiği görülmüştür. Salik ve Kaygın'ın (2016) araştırmasında da benzer şekilde girişimcilik kapsamında riske girme eğilimlerinde 26 ve üzeri yaş grubundakilerin lehine anlamlı farklılık olduğu görülmüştür. Fakhr Eldin'in (2017) araştırmasında da yaş değişkeninin, girişimcilerin duygusal zekâsı ile yeni girişim oluşturma arasındaki ilişkide düzenleyici bir rolü olduğu görülmüştür. Araştırma sonucundan farklı olarak ise Yavuz ve Yavuz'un (2017) araştırmasında girişimcilik eğilimlerinde yaş grupları arasında anlamlı bir fark bulunamamıştır. Öğretmenlerin empatik eğilimlerinin yaşa göre anlamlı bir fark göstermediğini tespit eden araştırmalar da mevcuttur (Çelik, 2008, Koç; 2016). Benzer şekilde duygusal tepkiler üzerine yapılan araştırmalarda da yaşın bir farklılık oluşturmadığını görmek mümkündür (Kunzmann ve Grühn, 2005; Silvers, McRae, Gabrieli, Gross, Remy ve Ochsner; 2012).Ergenlik yıllarında ise empati gelişiminin yaşa bağlı olarak arttığını gösteren 
bulgular da vardır (Allemand, Steiger ve Fend, 2015). Bu araştırmada ulaşılan yaş değişkeniyle ilgili sonuç, sınıf değişkeniyle birlikte değerlendirildiğinde; öğretmen adaylarının mesleki deneyim ve tecrübeleri arttıkça sosyal girişimcilik ve empatik eğilimlerinin dearttığı söylenebilir. Aynı zamanda yaşla birlikte edinilen olgunluğun ve yaşam deneyimlerinin de bu durumda bir payı olduğu düşünülebilir.

Bölüm değişkeni için sosyal girişimcilik puanlarında okul öncesi ve sosyal bilgiler öğretmenliği ile sınıf öğretmenliği bölümleri arasında okul öncesi ve sosyal bilgiler öğretmenliği lehine anlamlı fark olduğu görülmektedir. Empatik eğilim puanlarında ise, okul öncesi ve sosyal bilgiler öğretmenliği arasında okul öncesi öğretmenliği lehine anlamlı bir fark bulunmuştur. Aydın ve Öner'in (2016) araştırmalarında ise, ulaştığımız sonuçlardan farklı olarak bölüme göre (sosyal bilgiler öğretmenliği ve sınıf öğretmenliği) girişimcilik puanları arasında anlamlı bir fark bulunamamıştır. Empati ile ilgili Ekinci ve Aybek'in (2010) araştırmasında ise, bölüm değişkenine göre en yüksek ortalamaya okul öncesi öğretmenliğinin sahip olduğu görülmüştür.Diğer programlara kıyasla daha küçük yaş gruplarına hitap eden okul öncesi öğretmenliği programında öğrenim gören öğretmen adaylarının hem sosyal girişimcilik hem de empatik eğilim düzeylerinin yüksek çıkması hitap edilen yaş grubundan dolayı beklenebilir bir sonuçtur.

Sınıf değişkenine göre öğretmen adaylarının hem sosyal girişimcilik özellikleri hem de empatik eğilim puanlarında 1. sinıf ve 4. sinıf arasinda 4. sinıf lehine anlamlı fark olduğu tespit edilmiştir. Alanyazına bakıldığında,bu araştırmada elde edilen sonuçlardan farklı olarak, öğretmen adaylarının sınıf düzeyine göre girişimcilik ve sosyal girişimcilik puan ortalamaları arasında anlamlı bir farklılık bulunamadığı görülmektedir (Aydın ve Öner, 2016; Yavuz ve Yavuz, 2017). Öğretmen adaylarının empatik eğilimleriyle ilgili Ekinci ve Aybek'in (2010) yapmış olduğu araştırmada ise, 4. sinıfta okuyanların 1. sınıfta okuyanlara göre empatik eğilimlerinin daha yüksek olduğu görülmektedir.Öğretmen adaylarının son sınıflarda staj uygulamaları yoluyla öğrencilerle karşılaşması, yeni deneyimler edinmesi, uygulamalı ve öğretmenlik mesleğine yönelik derslerin son sınıfa doğru artması gibi durumlar ulaşılan bu sonucun nedenleri arasında sayılabilir.

Aile ile birlikte yaşanılan yerin niteliği değişkenine göre öğretmen adaylarının hem sosyal girişimcilik özellikleri hem de empatik eğilim puanlarında gruplar arası anlamlı bir fark görülmemiştir. Ateş (2018), araştırmasında öğretmen adaylarının sosyal girişimcilik puan ortalamalarına ilişkin kentsel yerleşim yeri ile kırsal yerleşim yerinde yaşamını geçirenler arasında yaşamının çoğunu kentsel bir yerleşimde geçirenlerin lehine anlamlı bir fark bulmuştur. Aydın ve Öner'in (2016) araştırmasında ise yaşanılan yerleşim birimi değişkenine göre öğretmen adaylarının girişimcilik düzeyleri köy ve büyükşehir arasında büyükşehir lehine anlamlı bir farklılık çıkmıştır. Akbulut ve Sağlam (2010) tarafından yapılan araştırmada sınıf öğretmenlerinin çalıştıkları yerleşim yeri değişkenine göre empatik eğilim puan ortalamaları arasında anlamlı bir farklılık bulunamamıştır.
Akademik not ortalaması değişkenine göre öğretmen adaylarının sosyal girişimcilik puanlarına ilişkin gruplar arası anlamlı bir fark olmadığı görülmektedir. Ancak empatik eğilim puanlarında,0- 2.49 ve 2.50 - 2.99 ile $3.00-$ 3.49 grupları arasında, $3.00-3.49$ grubunun lehine anlamlı fark olduğu ortaya çıkmıştır. Ballı ve Koca Ballı'nın (2014) araştırmasında ise üniversite öğrencilerinin girişimcilik eğilimleri ile genel not ortalamaları arasında 2.00 ve altı genel not ortalamasına sahip öğrenciler lehine anlamlı bir fark bulunmuştur. Diğer bir değişken empatiyle ilgili ise,ortaokul öğrencileriyle yapılan bir araştırmada da empatinin akademik performansla ilişkili olduğu sonucuna ulaşılmıştır (Bonner ve Aspy, 1984).

STK üyeliği ve STK aktivitelerine katılım değişkenleri açısından sosyal girişimciliğe ve empatik eğilime ilişkin öğretmen adaylarının puanları arasında anlamlı bir fark bulunamamıştır. Ancak Ateş (2018)'in sosyal girişimcilikle ilgili araştırmasında benzer içeriğe sahip değişkenlere göre (sosyal-kültürel etkinliklere katılma ve toplumsal sorunlarla ilgilenme durumu) sosyal girişimcilik puan ortalamaları arasında sosyal-kültürel faaliyetlere katılanların ve toplumsal sorunlarla ilgilenen öğretmen adaylarının lehine anlamlı bir fark tespit edilmiştir. Kaya'nın (2016) empati üzerine yaptığı araştırmada ise toplulukta aktif rol oynamak ile öğretmen adaylarının empati düzeyleri arasında anlamlı bir fark bulunamamıştır.

Empatik eğilim değişkeninin sosyal girişimcilik özelliklerini istatistiksel olarak anlaml bir şekilde yordadığı belirlenmiştir. Empatik eğilim değişkeni sosyal girişimcilik özelliklerinin toplam varyansının yaklaşık olarak \%23'ünü açıklamaktadır. Sosyal girişimciliğin yordanmasına yönelik yapılan benzer bir çalışmada (Ateş, 2018) sosyal bilgiler öğretmen adaylarının eleştirel düşünme eğilimlerinin sosyal girişimcilik özelliklerindeki toplam varyansın \%51'ini açıkladığı tespit edilmiştir. Benzer bir şekilde duygusal zekâ ve girişimcilik arasında anlamlı ve pozitif bir bulguya ulaşan araştırmalar da mevcuttur (Kashif, Khurshid ve Zahid, 2016; Neqabi ve Bahadori, 2012; Oriarewo, Agbim ve Zever, 2014).Dolayısıyla empatik eğilim düzeyleri yüksek olan bireylerin sosyal girişimcilik özelliklerine de sahip olduğu söylenebilir.

Araştırma sonucunda elde edilen bulgular 1şı̆̆ında öğretmen adaylarının empatik eğilimleri ve sosyal girişimcilik özellikleriyle ilgili çeşitli önerilerde bulunulabilir.Cinsiyet değişkeninde alanyazından farklı olarak empatik eğilim puanlarında erkeklerin lehine ulaşılan sonucun nedeni, bu farklı durumun aydınlatılabilmesi için derinlemesine araştırılabilir.Olumlu sosyal davranışlar ve toplumsal sorunların çözümüyle ilişkili olan empatik eğilim ve sosyal girişimcilik özelliklerinin, toplum yararına aktiviteler düzenleyen sivil toplum kuruluşlarıyla ilgili değişkenlerde neden gruplar arası anlamlı farklılık göstermediği incelenebilir.Ayrıca sınıf ve yaş değişkeninde hem empatik eğilim hem de sosyal girişimcilik özelliklerinde elde edilen sonuç göz önünde bulundurulduğunda, ne tür uygulamaların veya hangi yaşantıların bu sonucu doğurduğu araştırılabilir.

Öğretmen adaylarının son sınıfa doğru sosyal girişimcilik düzeylerinin arttığı tespit edilmiştir. Akademik not ortalaması değişkeninden elde edilen bulgu ise en yüksek 
ortalamalara sahip grubun değil o grubun bir seviye altında yer alanların sosyal girişimcilik özelliklerini daha çok sergilediğini işaret etmektedir. $\mathrm{Bu}$ iki bulgu sosyal girişimciliğin eğitimle ilişkisini bize göstermekle birlikte en başarılı grup lehine bir farklılık olmaması, eksik birtakım unsurların da olduğunu sezdirmektedir. Dolayısıyla sosyal girişimcilik özelliklerinde görülen bu artışın daha sağlıklı ve etkili olabilmesi için kapsaml, planlı ve sistematik bir sosyal girișimcilik eğitim programının düzenlenmesi önerilebilir. Bununla birlikte ilk sınıflarda ve erken yaşlarda sosyal girişimcilik özelliklerinin diğer gruplara göre düşük olduğu düşünüldüğünde, söz konusu sosyal girişimcilik dersinin lisans eğitim programının ilk dönemlerinde verilmesi önerilebilir. Empatik eğilimin sosyal girişimcilik özelliklerinin toplam varyansı içerisindeki payı göz önüne alındığında, sosyal girişimcilikle ilgili hazırlanacak programlarda empatik eğilimin de göz önünde bulundurulması programın niteliğinin yükseltilmesine yardım edebilir.

\section{Kaynakça}

Akbulut, E. ve Sağlam, H. İ. (2010). Sınıf öğretmenlerinin empatik eğilim düzeylerinin incelenmesi. Uluslararası Insan Bilimleri Dergisi, 7(2), 1068-1083.

Aksoy, T. (2013). Sosyal girişimcilik nedir?.(Erişim: 02.09.2018), http://www.temelaksoy.com/sosyalgirisimcilik-nedir/.

Allemand, M., Steiger, A. E. ve Fend, H. A. (2015). Empathy development in adolescence predicts social competencies in adulthood. Journal of Personality, 83(2), 229-241.

Alver, B. (1998). Bireylerin uyum düzeyleri ile empatik becerileri arasındaki ilişkiler.Yüksek Lisans Tezi. Erzurum:Atatürk Üniversitesi.

Ateş, Y. (2018). Sosyal bilgiler öğretmen adaylarının sosyal girişimcilik özelliklerinin ve eleştirel düşünme eğilimlerinin incelenmesi.Yüksek Lisans Tezi. Erzincan: Erzincan Üniversitesi.

Aydın, E. ve Öner, G. (2016). Sosyal bilgiler ve sınıf öğretmeni adaylarının girişimcilik düzeylerinin incelenmesi. Journal of Kirsehir Education Faculty, 17(3), 497-515.

Ballı, E. ve Koca Ballı, A. İ. (2014). Üniversite öğrencilerinin bireysel değerleri ve girişimcilik eğilimleri. Çukurova Üniversitesi Íktisadi ve İdari Bilimler Fakültesi Dergisi, 18(1), 101-121.

Barnett, M. A., Thompson, M. A. ve Pfeifer, J. R. (1984). Perceived competence to help and the arousal of empathy. The Journal of Social Psychology, 125(5), 679-680.

Besler, S. (2010). Sosyal girişimcilik. İçinde S. Besler (Ed.) Sosyal girişimcilik (s. 3-28). İstanbul: Beta Yayınları.

Betil, İ. (2010). Sivil toplum, sosyal sermaye, sosyal girişimcilik. Girişimcilik ve Kalkınma Dergisi, 5(1), 2125.
Bonner, T. D. ve Aspy, D. N. (1984). A study of the relationship between student empathy and GPA. Journal of Humanistic Education and Development, 22(4), 149-54.

Büyüköztürk, Ş. (2016). Sosyal bilimler için veri analizi el kitabı. Ankara: Pegem Akademi Yayınları.

Cohen, J. (1988). Statistical power analysis for the behavioral science. New Jersey: Lawrence Erlbaum Associates, Inc., Publishers.

Çelik, E. (2008). Okul öncesi eğitim öğretmenlerinin empatik eğilimlerinin bazı değişkenler açısından incelenmesi.Yüksek Lisans Tezi. Konya: Selçuk Üniversitesi.

Dees, J. G. (1998). The meaning of "social entrepreneurship". Stanford University: Draft Report for the Kauffman Center for Entrepreneurial Leadership.

Dinçyürek, S. (2004). Üniversite öğrencilerinin empatik becerilerinin çeşitli değişkenler açısından incelenmesi. Marmara Coğrafya Dergisi, 10, 95-116.

Dökmen, Ü. (1987). Empati kurma becerisi ile sosyometrik statü arasındaki ilişki. Ankara Üniversitesi Ĕ̆itim Bilimleri Fakültesi Dergisi, 20(1-2), 183-207.

Dökmen, Ü. (1988). Empatinin yeni bir modele dayanılarak ölçülmesi ve psikodrama ile geliştirilmesi. Ankara Üniversitesi Ĕ̆itim Bilimleri Fakültesi Dergisi, 2(1-2), 155-190.

Dökmen, Ü. (1998). İletişim çatışmaları ve empati. Ankara: Sistem Yayıncılık.

Ekinci, Ö. ve Aybek, B. (2010). Öğretmen adaylarının empatik ve eleştirel düşünme eğilimlerinin incelenmesi. Ilkögretim Online, 9(2), 816-827.

FakhrEldin, H. (2017). The relationship between the emotional intelligence of entrepreneurs and the new venture creation: The role of age, gender and motive. Arab Economic and Business Journal, 12(2), 99-108.

Fowler, A. (2000). NGDOs as a moment in history: beyond aid to social entrepreneurship or civic innovation?.Third world quarterly, 21(4), 637-654.

Genç, S. Z. ve Kalafat, T. (2010). Öğretmen adaylarının empatik becerileri ile problem çözme becerileri. Kuramsal Eğitimbilim Dergisi, 3(2), 135-147.

Goldman, M., Broll, R. ve Carrill, R. (1983). Requests for help and prosocial behavior. The Journal of Social Psychology, 119(1), 55-59.

Güler, B. K. (2008). Sosyal girişimciliği etkileyen faktörlerin analizi. Doktora Tezi. İzmir:Dokuz Eylül Üniversitesi.

Hanson, R. A. ve Mullis, R. L. (1985). Age and gender differences in empathy and moral reasoning among adolescents. Child Study Journal, 15(3), 181-188.

Karasar, N. (1995). Bilimsel araştırma yöntemi, Ankara: Sim Matbaacılık. 
Kashif, M., Khurshid, M. K. ve Zahid, I. (2016). Relationship between emotional intelligence and entrepreneurship. Research on Humanities and Social Sciences, 6(5), 22-26.

Kaya, B. (2016). An evaluation of the empathy levels of pre-service social studies teachers. Educational Research and Reviews, 11(6), 229-237.

Kickul, J. ve Lyons, T. S. (2012). Understanding social entrepreneurship: The relentless pursuit of mission in an ever changing world. New York: Routledge Publishing.

Koç, M. (2016). Demografik özellikler ile empatik eğilim arasındaki ilişki: yetişkinler üzerine ampirik bir araştırma. Igdir University Journal of Social Sciences, (9), 25-47.

Koçak, S. ve Özdemir, M. (2015). Öğretmen adaylarının okul yöneticiliğine yönelik tutumları üzerinde sosyal girişimciliğin rolü. Mersin Üniversitesi Eğitim Fakültesi Dergisi, 11(3), 631-645.

Konaklı, T. ve Göğüş, N. (2013). Aday öğretmenlerin sosyal girişimcilik özellikleri ölçeği: geçerlik ve güvenirlik çalışması. Gazi University Journal of Gazi Educational Faculty (GUJGEF), 33(2), 373-391.

Kunzmann, U. ve Grühn, D. (2005). Age differences in emotional reactivity: the sample case of sadness. Psychology and aging, 20(1), 47-59.

Mair, J. ve Marti, I. (2006). Social entrepreneurship research: A source of explanation, prediction, and delight. Journal of world business, 41(1), 36-44.

Mair, J. ve Noboa, E. (2003). Social entrepreneurship: how intentions to create a social enterprise get formed. Barcelona: IESE Business School Working Paper No. 521.

MEB. (2018). Öğretim programlart. Erişim tarihi: 12 Eylül 2018, http://mufredat.meb.gov.tr/Programlar.aspx

Myyry, L. ve Helkama, K. (2001). University students' value priorities and emotional empathy. Educational Psychology, 21(1), 25-40.
Neqabi, S. ve Bahadori, M. (2012). Relationship between emotional intelligence and entrepreneurial behavior. Iranian Journal of Military Medicine, 14(2), 123-128.

Oriarewo, G. O., Agbim, K. C. ve Zever, T. A.(2014). Relationship between emotional intelligence and entrepreneurial performance: The mediating effect of managerial competence. International Journal of Economics, Commerce and Management, 2(10), 1-16.

Pala, A. (2008). Öğretmen adaylarının empati kurma düzeyleri üzerine bir araştırma. Pamukkale Üniversitesi Eğitim Fakültesi Dergisi, 23(23), 13-23.

Salik, N. ve Kaygın, E. (2016). Demografik değişkenler açısından üniversite öğrencilerinin girişimcilik eğilimlerinin belirlenmesi: Kafkas üniversitesi örneği. KSÜ Sosyal Bilimler Dergisi, 13(1), 145-162.

Silvers, J. A., McRae, K., Gabrieli, J. D., Gross, J. J., Remy, K. A. ve Ochsner, K. N. (2012). Age-related differences in emotional reactivity, regulation, and rejection sensitivity in adolescence. Emotion, 12(6), 1235-1247.

Tutarel-Kışlak, Ş. ve Çabukça, F. (2002). Empati ve demografik değişkenlerin evlilik uyumu ile ilişkisi. Sosyal Politika Çalışmaları Dergisi, 5(5).

Ünal, G. (1997). Psikolojik danışmanlık ve rehberlik eğitimi alan öğrencilerin empatik eğilimlerinde gözlenen değişmeler (Selçuk Üniversitesi Eğitim Fakültesi örneği). Yüksek Lisans Tezi. Konya: Selçuk Üniversitesi.

Yavuz, A. ve Yavuz, H. İ. (2017). Girişimcilik eğilimlerinin belirlenmesi: Taşkent MYO öğrencileri üzerine bir araştırma. Mehmet Akif Ersoy Üniversitesi Sosyal Bilimler Enstitüsü Dergisi, 9(21), 89-100.

Yıldırım, A. ve Şimşek, H. (2008). Sosyal bilimlerde nitel araştırma yöntemleri. Ankara: Seçkin Yayıncılık

Zahra, S. A., Rawhouser, H. N., Bhawe, N., Neubaum, D. O. ve Hayton, J. C. (2008). Globalization of social entrepreneurship opportunities. Strategic entrepreneurship journal, 2(2), 117-131. 
